\title{
THE EFFECT OF LOW OIL AND GAS PRICES ON FREEHOLD OIL AND GAS LEASES: A PROBLEM OF INTERPRETATION'
}

\author{
RICHARD H. BARTLETT*
}

Freehold oil and gas leases seek to reconcile the interests of the lessor and the lessee by providing in the habendum a clause for an initial primary term and "so long thereafier as there is production ". Both Canadian and United States jurisprudence indicate that leases will terminate if production is not "in paying quantities".

A test as to whether or not oil or gas is being produced in paying quantities is whether the value of the oil or gas produced exceeds the operating costs. If production fails this test then it must be considered whether a reasonably prudent operator would have contimued to produce the well. It is suggested that a slight loss due to a temporary fall in price will not necessarily terminate a lease. But if the well was marginal before the fall in price. or if it extends over a substantial period of time, the holding of the lease by the lessee will most likely be construed as mere speculation.

Further, most shut-in clauses do not assist the lessee. The clauses generally assume the existence of a well capable of production "in paying quantities". However, the actual wording must govern and some clauses provide for "economical " or "unprofitable " markets and thereby specifically address the lessee's dilemma.

TABLE OF CONTENTS

I. INTERPRETATION OF FREEHOLD OIL AND GAS LEASES

II. RELEVANCE OF UNITED STATES JURISRUDENCE

III. A REQUIREMENT OF PRODUCTION IN PAYING QUANTITIES 5

IV. WHAT CONSTITUTES PRODUCTION OR PRODUCTION IN PAYING QUANTITIES?

V. THE RIGHT TO SHUT-IN 13

VI. CONCLUSION 16

$\begin{array}{ll}\text { VII. APPENDIX I } & 17\end{array}$

$\begin{array}{ll}\text { VIII. APPENDIX II } & 18\end{array}$

The freehold oil and gas lease represents an accommodation of the interests of the lessor and lessee. It seeks to reward the lessor for its ownership of the oil and gas and the lessee for assuming the risks of exploration and development. But what if oil and gas prices fall so low as to deny any appropriate royalty return to the lessor or profit to the lessee? In 1986 oil prices on the New York Exchange plummeted from $\$ 26.00$ U.S. per barrel to a low point on March 31 of $\$ 10.00$ U.S. per barrel. Oil prices have only partially recovered. Gas prices fell more slowly but have barely recovered at all.'

* University of Western Australia.

1. See generally J.T. Lane \& T.A. Heywood. "Maintaining Oil \& Gas Leases in Depressed Markets", Chap. 14. Eastern Mineral Law Foundation, 8th Am. L. Inst. 1987; T.P. Battle "Lease Maintenance in the Face of Curtailed/Depressed Markets". Chap. 16, Rocky Mt. MinL. Inst., 32nd Am. L. Inst., 1986; L.L. Weaver, "Evaluating the "Production" Status of Oil and Gas Leases". 23 Tulsa L.J. 667 (1988); and J.S. Lowe. "Current Lease and Royalty Problems in the Gas Industry " 23 Tulsa L.J. 547 (1988).

2. John F. Heilliwell et al.. Oil and Gas in Canada: The Effects of Domestic Policies in Canada, University of Calgary, Canadian Tax Paper No. 83 (Toronto: Canadian Tax Foundation, 1989). 
This paper explores the fundamental problems that are created by falling oil and gas prices with respect to the maintenance of oil and gas leases beyond their primary term. Must there be production in paying quantities and, if there is no production, what right does the lessee have to shut in the well? The problems are not considered to be merely academic. The analysis adopted in this paper suggests that some leases with marginal wells in Alberta and Saskatchewan may have terminated already or may terminate in the future. The analysis begins with a consideration of the appropriate manner of interpretation of freehold oil and gas leases and the relevance of United States jurisprudence.

\section{INTERPRETATION OF FREEHOLD OIL AND GAS LEASES}

"[T]he actual wording and terminology of the agreement itself if clear must, of course, govern at all times." ${ }^{\prime 3}$ In the early interpretation of freehold oil and gas leases by the Canadian courts, after Leduc, there was a tendency to apply a "literal plain meaning" approach to the language used. The approach was typified, of course, by the decision of the Supreme Court of Canada in Shell Oil Co. v. Gibbard,${ }^{4}$ where the court effectively rendered the conventional pooling clause meaningless. Locke J. explained that the "language . . . is to be construed literally in accordance with the plain meaning of the language employed."'s The approach caused one commentator to complain: ${ }^{\circ}$

As long as the Courts continue to construe leases so literally as to ignore the basic purpose of the lease

it is doubtful that a lease will ever be drafted successfully to protect the interest and rights of the lessee.

However, the courts have changed their approach. After the mid-1960's the Courts adopted a more purposive approach, ${ }^{7}$ perhaps as a result of greater familiarity with the oil and gas lease or more probably because of greater deference to the views of the Alberta Court of Appeal. ${ }^{8}$ Whatever the reason by the time of Cull v. Canadian Superior Oil Ltd. a different approach is evident. In the Appellate Division of the Supreme Court of Alberta" Johnson J.A. demanded a "resonable" interpretation keeping "in mind the realities of the situation and the purposes which are contem-

3. Telstar Resources Lid. v. Coseka Resources Lid. et al. (1980), 12 Aita L.R. (2d) 187 at 190 (C.A.), Morrow J.A. Also see Kissinger Petroleums Lid. v. Keith McLean Oil Properties Lid. et al. (1984), 33 Alta L.R. (2d) 1 at 16 (C.A.), McDermid J.A.: "If the language clearly provided for such a result, so be it .. ."; Canada Cities Service Petroleum Corp. v. Kininmonth, [1964] S.C.R. 439 at 447-448, 47 W.R.R. 437, where Martland J. observed: "the essential task in the present case is to construe the terms of the lease which is in question.; Republic Resources Lid. v. Ballem (1981), 17 Alta L.R. (2d) 235 at 243 (Alta. (Q.B.).

4. [1961] S.C.R. 725.

5. Ibid.

6. J. Currie, "Recent Cases and Developments in Oil and Gas Law" (1971) 9 Alta L. Rev. 452 at 463.

7. See Canadian Superior Oil of California Ldd. v. Kanstrup, [1965] S.C.R. 92 at 101, 47 D.L.R. (2d) 1 at 9, where Martland J. refers to the "object" of the clause in contention.

8. Compare: Canadian Cities Services Petroleum Corporation v. Kininmonth. [1964] S.C.R. 439 and Canadian Superior Oil of California Lid. v. Kanstrup, [1965] S.C.R. 92.

The Alberta Court of Appeal had always shown a greater regard for a purposive construction of the lease: compare Shell Oil Company v. Gunderson (1959), 28 W.W.R. 506 (Alta C.A.), [1960] S.C.R. 424, and Shell Oil Company v. Gibbard (1961), 34 W.W.R. 117 (Alta C.A.), [1961] S.C.R. 725.

9. (1970), 75 W.W.R. 606 (Alta C.A.). 
plated by the lease."10 In the Supreme Court of Canada," Martland J. recited the judgment of Johnson J.A. at length and agreed with the conclusion of the Appellate Division. The decision upheld the validity of a lease, in as much as the obtaining of production with "reasonable diligence and dispatch" after completion, albeit a six day gap, constituted production within the meaning of the habendum. The purposive approach evident in the Cull decision was described as "a liberalization" in 1983 in Canadian Superior Oil v. Crozet Exploration. ${ }^{12}$ The most recent utterance by the Alberta Court of Appeal upon the proper method of interpretation of a freehold oil and gas lease is fully in accord with this pattern. In Kissinger Petroleums Ltd. v. Keith McLean Oil Properties Ltd. ${ }^{13}$ the Court upheld the validity of a lease upon a "reasonable construction" of its terms and upon an examination of the realities of drilling, production and marketing with a regard to the consequences of other constructions. McDermid J.A. commented on the appellant's suggested construction: ${ }^{14}$

No lessee would enter into such a lease and no reasonable lessor would expect a lessee to consent to such a term. If the language clearly provided for such a result, so be it; but where there is any other reasonable construction, such should be adopted. A court should adopt a construction which results in a reasonable result rather than one which gives an unreasonable result.

The above analysis of the approach to the judicial interpretation of oil and gas leases would reject the suggestion by J.B. Ballem that the "common theme that runs throughout all the judgments is that of strict attention to the actual wording of the particular lease itself, and a determinably literalistic application of that language." 15 Ballem, in the second edition of his work, has recognized that there may perhaps be a change in approach but ascribes it to the Kissinger decision. ${ }^{16}$ It is suggested, on the contrary, that a new approach was evident at least as early as the Cull decision. Ballem further asserts that: ${ }^{17}$

the strict approach of the Supreme Court was not imposed on the Alberta Court of Appeal but was consistent with its own judgments. Accordingly, the Alberta Court of Appeal would only be following its own example if it continued to interpret the lease strictly.

It is suggested, again to the contrary, that the approach of the Alberta Court of Appeal was not that of strict construction. In the classic cases of a strict and nonpurposive construction, the Gibbard and Kininmoth decisions, the Supreme Court imposed an analysis wholly at variance with that of the Court of Appeal. The Court of Appeal in both cases adopted a reasonable purposive approach.

If uncertainty or ambiguity of meaning is still present upon application of the reasonable purposive approach, the contra proferentem rule is applicable. Locke J. referred to the rule in Shell Oil Co.v. Gibbard. 18

The lease, as stated, was proposed in its present form by Griffith [the lessee] and, in my opinion, if there was ambiguity in the language employed and doubt raised as to the meaning of such language, it should, if need be, be construed in accordance with the maxim verba chartarum fortius acciptiuntur contra proferentem (Leake on Contracts, 8th ed. [1931], p. 158).

10. Ibid at 611 .

11. [1972] S.C.R. 89.

12. (1982), 33 D.L.R. (3d) 53 (Alta Q.B.).

13. (1984), 33 Alta L.R. (2d) I.

14. Ibid. at 16 .

15. J.B. Ballem, The Oil and Gas Lease in Canada. (Toronto: University of Toronto Press, 1985) at 87.

16. Supra, note 13.

17. Ibid.

18. Supra, note 8. 
The excerpt from the judgment was recited by McDermid J.A. in Kissinger. ${ }^{19}$ In neither case did the Court consider that there was an ambiguity present and accordingly in neither case was the rule applied. The rule contemplates that in the event of ambiguity or uncertainty a document should be construed against the party who prepared it. In the case of oil and gas leases, it is usually the lessee. The difficulty is to determine when an ambiguity or uncertainty is present.

Lewis and Thompson ${ }^{20}$ cite Canadian Fina Oil Ltd. v. Paschke ${ }^{21}$ as authority for the proposition that a "lease is to be constued in the lessor's favour to promote development and to prevent delay." This would seem to be a considerable overstatement of the proposition which Porter J.A. sought to make in that case. He merely sought to affirm that time was of the essence in the oil production business and leases were to be construed accordingly. He observed: ${ }^{22}$

... the people of this province . . . have seen what was in common parlance called 'cow pasture' turned overnight from areas of hope alone, to reservoirs containing thousands of barrels per acre. It is implicit in the search for oil, and indeed in its production and marketing, that events affecting these activities can occur with great suddenness unpredictably. In consequence there are heavy shifts of value and necessary new almost instant reappraisals of ventures to be undertaken.

That "time is of the essence" is merely one aspect of the high risk nature of the oil and gas business. The high-risk nature of the business was cited as a factor in denying recovery of the costs of drilling a well to the plaintiff in Republic Resources Ltd. v. Ballem. ${ }^{23}$ Holmes J. observed: $:^{24}$

One cannot overlook that the plaintiffs were engaged in oil and gas exploration and development, by its nature a high-risk business.

The high-risk nature of the oil and gas business, the importance of time and costs of delay are proper factors to be considered in applying a "reasonable" construction which recognizes the "realities" of the situation.

\section{RELEVANCE OF UNITED STATES JURISPRUDENCE}

The relevance of United States jurisprudence would seem self-evident. Both Lewis ${ }^{25}$ and Ballem ${ }^{26}$ have explained how the form of the Canadian freehold oil and gas lease is derived from patterns developed in the United States. It would seem natural for Canadian courts to consider how United States courts have interpreted oil and gas leases with similar language and objects. This is what Canadian courts have generally done. As Morrow J.A. explained in Telstar Resources Ltd. v. Coseka Resources Ltd.:27

Canadian courts have consistently accepted help in the use and interpretation of terms in the oil and gas business from the courts in the United States because of their much wider experience in problems arising from the development of oil and gas fields and the production of these substances: Wulff v. Lundy, [1940] 1 W.R.R. 444 at 454. [1940] 2 D.L.R. 126 (Alta C.A.); and Oil City Petroleums (Leduc) Ld. v. Amer Leduc Petroleums Lid. 2 W.W.R. (N.S.) 371 at 380, [1951] 3 D.L.R. 835, affirmed [1952] 3

D.L.R. 577 (Can.).

19. Supra, note 13 at 16.

20. D. Lewis \& A. Thompson, Canadian Oil and Gas, (Toronto: Butterworths, 1971).

21. (1957), 21 W.W.R. 260 (Alta C.A.).

22. Ibid. at 263.

23. Supra, note 3.

24. lbid. at 250.

25. D.E. Lewis, "The Canadian Petroleum and Natural Gas Lease" (1952) 30 Can. Bar Rev. 965.

26. J.B. Ballem, supra, note 15 , at 6-8.

27. (1980), 12 Alta L.R. (2d) 187 at 190 (C.A.). 
The cases collected in Appendix I demonstrate the accuracy of Morrow J.A.'s comment with respect to the interpretation of oil and gas leases. Not only have the Canadian courts considered the United States jurisprudence, but they have also invariably applied it. This is to be expected following the initial adoption of United States jurisprudence in framing the obligation of lessor and lessee in leading cases such as East Crest Oil Co. Ltd. v. Strohschein ${ }^{28}$ and Wetter v. New Pecalta Oils Co. Ltd. et al. ${ }^{29}$ There are exceptions, or exceptions in part, but they tend to be decisions which have attracted criticism, (see Appendix II). They include Canadian Fina Oil Ltd. v. Paschke, ${ }^{30}$ Shell Oil Co.v. Gunderson ${ }^{31}$ and Shell Oil Co. v. Gibbard. ${ }^{32}$ In recent years the exceptions have become fewer, in accordance with the observations of Morrow J.A. in 1981 in Telstar Resources. The interpretation of the freehold oil and gas lease in Canada owes much to the United States jurisprudence..$^{33}$ Moreover, in the absence of Canadian authority it is a jurisprudence which seems eminently appropriate for consideration.

\section{A REQUIREMENT OF PRODUCTION IN PAYING QUANTITIES}

The conventional freehold oil and gas lease seeks to reconcile the interests of the lessor and the lessee by providing in the habendum clause for an initial primary term and "so long thereafter as there is production". The clause seeks to allow the lessee to both recover and obtain a return on its investment in the drilling of a well, but only as long as there is production. But what constitutes production?

The "actual wording . . . must, of course, govern at all times". The classic form of wording adopted in post Leduc leases is:

"To have and enjoy the same for the term of __ years from the date hereof, and so long thereafter as the said substances or any of them are being produced from the said lands . . ." [Imperial]

Many such leases are still in operation and such leases are still being entered into. ${ }^{35}$ The Canadian Association of Petroleum Landmen (C.A.P.L.) 88 petroleum and natural gas lease is also in common use. It provides:

"To have and enjoy the same for the term of __ years (herein called the "primary term") commencing on the date hereof and continuing so long thereafter as operations (as hereinafter defined) are conducted upon the said lands . ...

" $\mathrm{l}(\mathrm{g})$ "operations" means any of the following . . .

(ii) the production of any leased substance. . ."

Some leases have sought to particularize the meaning to be given to "production": "... for the year of _ years from the date hereof . . . and so long thereafter as operations, as hereinafter defined, are conducted upon the said lands . . .

... “operations" shall mean any of the following . . Production of the leased substances or any of them (whether or not in paying quantities) . . ." [Shell, Norcen]

28. (1952), 2 D.L.R. 432 (Alta C.A.).

29. [1951] 2 W.W.R. 290 (Alta C.A.).

30. (1957), 21 W.W.R. 260 (Alta C.A.).

31. [1960] S.C.R. 424.

32. [1961] S.C.R. 725 .

33. Compare J.B. Ballem, supra, note 15 at 86-87.

34. See Canada Cities Service Petroleum v. Kininmonth, supra, note 8.

35. The author conducted a survey of freehold oil and gas leases in use in the Spring of 1990. 
A converse particularization is provided by the following language:

... for the primary term and so long thereafter as any of the leased substances is being produced or is capable of production in paying quantities from a well or wells on the said lands ... [Pan Canadian]

Some of the leases which refer to "production in paying quantities" have sought to define its meaning: ${ }^{36}$

"paying quantities" means an output of leased substances or any of them from a well in quantities that, after a reasonable production test or a reasonable period of production, would warrant the taking of such production, considering:

(i) in the case of a well not yet completed, the cost of completing and producing operations, the probable life of the well, the available (or potentially available) market and the price, kind and quality of such production, and

(ii) in the case of a completed well, all factors listed in item (i) hereof except for the cost of completing operations:" [Norcen]

or more simply:

.. 'production in paying quantities' means the output from a well of such quantity of the leased substances or any of them as can be taken profitably having regard only to the costs of producing such substances and not to the costs of the drilling of such a well." [Pan Canadian]

The classic form of the post-Leduc lease and the C.A.P.L. 88 lease do not particularize the meaning of "production of any leased substance". There is no reported Canadian case that directly explains its meaning. In Krysa v. Opalinski ${ }^{37}$ production from three oil wells stopped for fifteen to twenty-one months because in the opinion of the lessee "having regard to all the circumstances of the case, particularly the condition of the said well, and the economic circumstances of the operators thereof and the leases and their assigns, continued production was not warranted." 38 The Court applied East Crest and concluded that the lease had terminated, sustaining the fairly clear proposition that in order to maintain the lease there must be at least some production, and economic difficulties and low prices afford no excuse.

The Canadian decision that comes closest to offering any insight as to the meaning to be given to "produced" is Stevenson v. Westgage ${ }^{39}$ The Ontario Supreme Court relied on United States decisions. It treated as synonymous the expressions "produced" and "found in paying quantities". The Court held that there was production in paying quantities and upheld the validity of the lease. The Ontario Court of Appeal ${ }^{40}$ upheld the decision. Stevenson v. Westgate, in the absence of any other Canadian decision, suggests that the courts must look to the United States jurisprudence for assistance. The freehold oil and gas lease introduced in Canada after Leduc was based on the "Producers Form 88" developed in the United States. The Producers Form 88 has almost identical language to that found in the classic post-Leduc Canadian lease and in the CAPL lease:

". . this lease shall remain in force for a term of — years from this date (called "primary term") and as long thereafter as oil, liquid hydrocarbons, gas or other respective constituent products, or any of them, is produced from said land"." [Producers Form 88]

36. "Production in paying quantities" is of course to be distinguished from "commercial production", see Farmers Mutual Petroleum v. U.S. Smelting, [1962] 39 W.W.R. 682 (Sask. Q.B.), Northwestern Utilities v. Peyto Oils (1983), 48 A.R. 1 at $27-28$ (Q.B.).

37. (1960), 32 W.W.R. 346 (Alta S.C.).

38. Ibid. at 348 .

39. [1941] 2 D.L.R. 471 (Ont. S.C.).

40. [1942] I D.L.R. 369 (Ont. C.A.).

41. See E. Kuntz, The Law of Oil and Gas, Vol. 2 (Cincinnati: Anderson Publishing, 1989), s. 2' and H.R. Williams, Oil and Gas Law, Matthew Bender, 1989, Vol. 3. s. 604.5. 
In almost all U.S. States and throughout the West, including Texas and California, ${ }^{42}$ the language has been construed to require production sufficient to pay a profit to the lessee. The landmark case is from the Supreme Court of Texas, Garcia v. King. ${ }^{43}$ The lease provided:

. . . this lease shall be for a term of ten years from this day (called primary term) and as long thereafter as oil, gas and other minerals are produced from said land hereunder.

During an eight month period production averaged only 24 barrels per month, which was insufficient to meet the lessee's costs of operating the wells. Moreover, the lessor received only eight cents per day as royalty. The Court held that the lease had terminated. The court considered that the object of the contract had in view the mutual benefit of both parties:

"In order to understand and properly interpret the language used by the parties, we must consider the object and purposes intended to be accomplished by them in entering into the contract. The object of the contract was to secure development of the property for the mutual benefit of the parties. It was contemplated that this would be done during the primary period of the contract."

The benefit sought by the lessor and lessee was assessed as follows:

"So far as the lessees were concerned, the object in providing for a continuation of the lease for an indefinite time after the expiration of the primary period was to allow the lessees to reap the full fruits of the investments made by them in developing the property. Obviously, if the lease could no longer be operated at a profit, there were no fruits for them to reap. The lessors should not be required to suffer a continuation of the lease after the expiration of the primary period merely for speculation purposes on the part of the lessees. Since the lease was no longer yielding a profit to the lessees at the termination of the primary period, the object sought to be accomplished by the continuation thereof had ceased, and the lease had terminated." 4

An approach which considers the objects and purposes of the lease is fully in accord with Canadian approaches to the construction of a lease. The conclusion that the object of the lease is "the development of the property for the mutual benefit of the parties" seems equally consistent therewith.

With a similar effect is the leading case of Gypsy Oil Co. v. Marsh ${ }^{45}$ from the Supreme Court of Oklahoma. In that case the lessee had discovered oil in small quantities in a shallow sand and was attempting to hold the lease beyond the primary term by producing from that sand in order to drill to deeper sand at a later date. The habendum clause was in classic form: "to have and to hold the same for a term ending _, and as long thereafter as oil or gas or either of them is produced from said land . . .". The Court held that the lease had terminated and explained: ${ }^{46}$

42. The Canadian law of the oil and gas lease is fundamentally derived from the jurisprudence developed in Texas and California, see East Crest Oil v. Strohschein (1952), 2 D.L.R. 432 (Alta C.A.).

The leading cases in the States are:

Texas: Garcia v. King 139 Tex. 578, 164 S.W.2d 509 (1962)

California: Barnard v. Gibson 224 P.d. 2d 90, (1950)

Arkansas: Turner v. Reynolds Metal 721 S.W.2d 626, (1986)

Kansas: $\quad$ Texaco Inc. v. Fox 618 p.2d 844 (1980)

Louisiana: Caldwell v. Alton Oil 161 La. 139, 108 So. 314 (1926)

Montana: Steven v. Potlach Oil 80 Mont. 239, 60 Pac. 119 (1927)

Nebraska: Kirby v. Holland 316 N.W.2d 746 (1982)

Oklahoma: Gypsy Oil v. Marsh 121 Okla. 135, 248 Pac. 329 (1926)

Tennessee: Waddle v. Lucky Strike Oil 551 S.W.2d 323 (1977)

Illinois: Doty v. Key Oil 404 N.E.2d 346 (1980)

43. 139 Tex. 578, 164 S.W.2d 509 (1942).

44. Ibid. at 512 .

45. 121 Okla. 135, 248 Pac. 329, 48 A.L.R. 876 (1926).

46. Ibid. at 333 and 883 . 
... the very purpose of the landowner in executing the lease is to have the oil and gas on the leased premises produced and marketed so that he may receive his royalty therefrom, and the purpose of the lessee is to discover and produce oil and gas in such quantities as will yield him a profit. There are material elements to be considered in the interpretation of the contract, and if consideration is given these elements, it must be held that the word 'produce', when used in this connection, means something more than mere discovery of a trace of oil or gas, or the discovery thereof in quantities so small as to render operation of the well unprofitable. Such a well would be of no benefit to either party.

The dominance of the view of "produced", requiring that the lessee show a profit, caused a leading commentator to write as long ago as 1952 that if lessees sought a different understanding, the phrase "whether or not in paying quantities" should be inserted in the lease..$^{47}$

It would appear that the only ${ }^{18}$ U.S. State which has purported to adopt a wholly different view of the meaning of "produced", albeit in obiter dicta, is Mississippi. In Roberts v. Corum ${ }^{49}$, a decision of the Supreme Court of Mississippi, the lease was in the classic form:

"'this lease shall be for a term of the ten (10) years from this date (called 'primary term') and as long

thereafter as oil, gas or other mineral is produced from said land . . .

A gas well produced profitably until August 1, 1953. Actual production, albeit not profitably, continued until April 8, 1954. On May 7, 1954 drilling of another well commenced. The Court held that the lease did not terminate on August 1, 1953 because an express provision of the lease maintained it in effect as long as drilling occurred within the specified period. But the Court also considered the question apart from such express provision and in obiter dicta, declared: ${ }^{50}$

47. Masterson, "Discussion Notes", 1 Oil \& Gas Reporter 23 (1952).

48. A view at slight variance is that of Kentucky. In Cumberland Contracting Co. v. Coffey, 405 S.W.2d 553 at 555 citing Flanagan v. Marsh 105 S.W. 424, 32 Ky. LawRep 184, the Kentucky Court of Appeal held that a lease had terminated, when following a period of profitable production, production fell to three barrels a month. The Court cited the substantial investment of the lessee and cited the Kentucky Supreme Court's earlier decision in Enfield v. Woods, 198 Ky. 328, 248 S.W. 842 at 843 (Kentucky Sup. Ct.) where it was observed:

"This, of course, means a production of oil and gas in such qualities as to be susceptible of division, so as to pay the landowner a royalty, even though small.

"A mere showing of oil manifestly is not sufficient, even though produced. The production must be tangible and substantial, but it need not be great."

In Cumberland the Court emphasized that "the payment of a reasonable royalty, considering all the circumstances in each case, is the object of leasing oil and gas rights" and cited with approval, the observation in 405 S.W.2d 553 at 555 citing Flanagan v. Marsh 105 S.W. 424, 32 Ky. Law Rep. 184.:

The lessee will not be permitted to hold the land for speculative or other purposes for an unreasonable length of time for a mere nominal rent, when a royalty on the product is the chief object in the execution of the lease."

The Court concluded that the "only object of holding over by the lessee was the chance (speculation) that at some future date secondary methods of production could be applied to the production of more oil." Ibid. at 555.

It has been suggested, (E. Kuntz, The Law of Oil and Gas, (Anderson Publishing, Cincinnati, 1989) at Vol. 2, s. 26.5, p. 337), that West Virginia adopted a different view to the majority of States, and such may have been the case in the past. But recent decisions have adopted the view of the majority and have stressed the lessor interest in royalties, Berry Energy Consultants v. Bennett 331 S.E.2d 823 at 826 (W.Va. 1985), and that "the objective of the lease is not merely to have oil or gas flow from the ground but to obtain production that is commercially profitable to both parties," Goodwind v. Wright 255 S.E.2d 924 at 926 (W.Va. 1979).

49. 112 So.2d 550, 10 Oil \& Gas Reptr. 779 (1959, Miss.).

50. lbid. at 554. 
There is nothing ambiguous in the use of the word "production" and we are not authorized to enlarge upon it, or detract from it. or to ascribe to it a meaning which the parties themselves did not see fit to ascribe to it. The instrument. therefore. must be construed according to its plain language. If the parties had intended that the word "production" should mean production in paying quantities, it would have been a very easy thing to write that into the lease. They did not see fit to do so.

But what of the overwhelming jurisprudence to the contrary? ${ }^{\text {si }}$

We are cognizant of the fact that many courts hold to the contrary and they are the authorities upon which the appellants rely. We think, however, that it is the sounder policy to adhere to the principles so deeply embedded in our jurisprudence that the plain and unambiguous language of a contract should be construed as written.

The Court, however, also concluded: ${ }^{52}$

We are of the opinion that even if it be conceded that the word "production" as used in the lease should be construed to mean production in paying quantities. the lease did not terminate upon the cessation of production in paying quantities under the facts of this case.

The Court thereby even further discounted the weight to be accorded to its obiter opinion.

The Court purported to apply the "plain" meaning of the language. It had no regard to the objects of the lease or any surrounding circumstance. It is suggested that the approach of the Mississippi Supreme Court to the interpretation of oil and gas leases has been rejected by the Supreme Court of Canada as early as the Cull decision in 1972. It was never an approach favoured by the Alberta Court of Appeal.

As a result, it is concluded that the meaning of "produced" in Canadian oil and gas leases should properly be construed with regard to the object of the lease. The object of the lease is to develop the resource for the mutual benefit of both the lessor and lessee. The lessor is entitled to a reasonable royalty and the return of the resource if such is not paid. The lessee is entitled to a reasonable opportunity to recover the costs of developing the property and a return for the investment and not merely to hold the land for speculative purposes awaiting a change in circumstances. The United States jurisprudence has accordingly determined that production needs to be profitable in order to maintain the lease in effect. This conclusion is suggested to be the appropriate result in Canada as well; a fortiori when, at the time of Leduc and the adoption of the United States form of lease in Canada, it was already being observed in the United States that if a different meaning were intended the phrase "whether or not in paying quantities" should be added.

Ballem does not agree with this conclusion. He observes: ${ }^{53}$

So far this issue has not arisen in Canada in connection with the 'are produced' language. In view of the approach taken by the Supreme Court on other aspects of the lease, it must be considered highly unlikely that the words would be enlarged to include any economic or volume conditions. If an operator is prepared to physically produce a well, regardless of profit or loss. it is submitted that a Canadian court would hold that the 'are produced' test had been met.

Ballem's reasoning is unchanged between his first and second editions, although elsewhere in the second edition he acknowledges a change in method of interpretation of oil and gas leases. It is suggested that Ballem's conclusion is founded on his suggestion that the courts will construe the oil and gas lease in a literal manner. It is suggested, as explained above, that such is not the approach of the Canadian courts today. The courts will employ a reasonable purposive construction of the lease having

51. Ibid. at 555.

52. Ibid.

53. J.B. Ballem, supra, note 15 , at 111 . 
regard to the object of the arrangement. Such an analysis entails a rejection of Ballem's views and that of the only state in the United States which has expressed a similar view, Mississippi.

\section{WHAT CONSTITUTES PRODUCTION OR PRODUCTION IN PAYING QUANTITIES?}

The United States courts have equated the terms "produced" and "produced in paying quantities",,${ }^{54}$ as is expressed in the landmark case of Garcia v. King: $: 55$

If a well pays a profit, even small over operating expenses, it produces in paying quantities, though it may never repay its costs and the enterprise as a whole may prove unprofitable.

A commentator on United States oil and gas law has sought to define it as: ${ }^{66}$

... such production as will enable the lessee to realize a profit from the sale of oil, gas or other minerals after the marketing expenses and the current cost of operation are deducted.

As explained by the Supreme Court of Texas: ${ }^{57}$

The underlying reason for this definition appears to be that when a lessee is making a profit over the actual cash he must expend in order to produce the lease, he is entitled to continue operating in order to recover the expense of drilling and equipping, although he may never make a profit on the overall operation.

The only reported Canadian decision has adopted a similar understanding of the meaning to be given to the expression "found thereon in paying quantities". It relied upon United States decisions to reach that understanding. In Stevenson v. Westgate ${ }^{58}$ the lessees sold $\$ 539.17$ of oil and expended over $\$ 4,000.00$ in capital expenses. The cost of operating the well was $\$ 228.89$. Makins J. in the Ontario Supreme Court cited United States decisions at length on the meaning of "produced" and "produced in paying quantities," and declared: ${ }^{59}$

... the test as to whether or not oil is being produced in paying quantities is not calculated in relation to the amount spent in organizing, equipping and putting the place in order that drilling should be commenced. The true test is what the relation is between the oil produced and the cost of running, operating expenses. This, of course, may include the one eighth payable to the defendants [lessors].

The Ontario Court of Appeal adopted the same construction observing: ${ }^{60}$

While appellants [lessors] are entitled to have a construction placed upon these words that will assure them of the continued operation of any well upon their land, so that they may be assured of a reasonable return so long as respondents [lessees] continue to occupy, at the same time this is a business arrangement, and regard must be had to the reasonable requirements of the business.

54. Garcia v. King 139 Tex. 578, 164 S.W.2d 509 at 511 (1942).

55. Ibid.

56. H.R. Williams, supra, note 41 , s. 604.6(a).

57. Clifion v. Koontz 160 Tex. 82, 325 S.W.2d 684 (1959). This understanding of what constitutes 'production' for the habendum explains the different meaning given to "production in paying quantities" or "commercial production" for the purpose of considering the obligation to drill off-set or development wells. The understanding in the latter context has regard to the "entire cost of drilling, equipping and operating the well so drilled," not merely current operating costs. H.R. Williams, supra, note 41, s. 604.6(a); Humphrey v. Placid Oil 142 F.Supp. 246

(E.D.Tex., 1956). In accord: Farmers Mutual Petroleum v. U.S. Smelting, supra, note 36, Northwestern Utilities v. Peyto Oils, supra, note 36, at 27-28.

58. [1942] 1 D.L.R. 369 (Ont. C.A.).

59. [1941] 2 D.L.R. 471 at 475 (Ont. S.C.).

60. Supra, note 58 , at 371 . 
The Court upheld the validity of the lease.

Upon the application of the test enunciated in Stevenson v. Westgate a marginal well may be considered to be no longer producing following a fall in oil and gas prices. Consequently, the lease terminates. Canadian authority is at present limited to this test.

But some U.S. States have developed both an "accounting" and "lessee" aspect to the determination of whether oil and gas is "produced." 61 The well must, from an accounting aspect, show a profit to the lessee on the current account. If a well fails to meet that test then it must be considered, from the aspect of the lessee, whether a reasonably prudent operator would continue to operate the well. The Texas Court of Civil Appeals explained in Ballanforte v. Kimbell:62

Lessors who seek to obtain a judgment that a lease is cancelled for cessation of production because it has become less than 'in paying quantities' are obliged to prove not only that the production is such that the lessees are not making a profit from operation devoted to production, but furthermore that a reasonably prudent operator would not have continued under the circumstances in the attempts devoted to obtaining such production. Skelly Oil Company v. Archer ${ }^{63}$ From this opinion it is inferred that there may be instances in which, as a matter of law, an operating lessee is not making a profit from activities instituted to obtain production but that nevertheless the fact question persists as to whether a reasonably prudent operator would have continued such activities under existent circumstances.

The factors to be considered in determining whether or not there is "production" are necessarily those which would influence a reasonably prudent operator. The Supreme Court of Texas explained in Clifton v. Koontz: ${ }^{64}$

In determining paying quantities, in accordance with the above standard, the trial court necessarily must lake into consideration all matters which would influence a reasonable and prudent operator. Some of the factors are: The depletion of the reservoir and the price for which the lessee is able to sell his produce, the relative profitableness of other wells in the area, the operating and marketing costs of the lease, his net profit, the lease provisions, a reasonable period of time under the circumstances, and whether or not the lessee is holding the lease merely for speculative purposes.

The question provoked by the fall in oil prices in 1986 and the continuing fall in gas prices since 1985 is the relationship of such declines in price to the position of the reasonably prudent operator. If a well no longer shows a profit in the current account due to a fall in price, in what circumstances does the lease terminate?

Only two cases have considered the question. Both concerned wells which after a fall in price resulted in production of slight losses. In Denkerv. Mid-Continent Petroleum Corp. ${ }^{65}$ the lease had produced a substantial profit over a 15 year period. The Court observed that the slight "loss will continue until there is either an increase in the price of oil or in production. New methods being developed will probably increase production." ${ }_{66}$ The Court then declared: ${ }^{67}$

Ever since the commencement of this action the oil industry has been and still is passing through a period of depression and many oil producing operations, due to the low price of crude oil, are being carried on at a loss, which under normal conditions would result in profit.

We are of the opinion that the parties, when they used such phrase [production] contemplated normal conditions and not the unusual conditions to which we have referred, and intended that the question of whether the requirements thereof were being met should be determined in the lights of such normal

61. But not all States: see Turner v. Reynolds 721 S.W.2d 626 (Ark. Sup. Ct., 1986).

62. 373 S.W.2d 119 at 121, 19 Oil \& Gas Reptr. 826 at 828 (1963).

63. 163 Tex. 336 at 356, S.W. $2 d 774$ at 783 (1961).

64. 160 Tex. 82 at 89,325 S.W.2d 684 at 691 (1959).

65. 56 F.2d 725, 84 A.L.R. 756, (10th Circ. 1932).

66. Ibid. at 727 .

67. Ibid. at $727-728$. 
conditions; and that if the wells would produce a profit over operating expenses under normal conditions and the Petroleum Corporation is willing to continue to operate them at a loss believing in good faith that normal conditions will return and the wells will ultimately produce a profit over operating expenses, it cannot be said that the wells are not producing oil in paying quantities within the meaning of the lease.

One of the wells on this lease is producing three barrels a day. Such wells usually continue to produce for a long period of time. It is common knowledge that three-barrel wells under normal conditions can be operated at a profit. It is our conclusion therefore that the lease has not terminated by reason of failure to produce oil from the lease premises.

Barley v. Singer, ${ }^{68}$ before the Supreme Court of Oklahoma, concerned a gas well which was operating at a slight loss, but continued to produce because legislation before Congress offered the hope of an increase in gas prices. In the result, the legislation passed and caused production of the gas well to be "in paying quantities". The Court relied on expert evidence that a reasonably prudent operator would have continued to produce the well in such circumstances.

The facts of the two cases indicate that slight losses due to a fall in price will not necessarily terminate a lease. But if the loss is substantial, that is the well was marginal before the fall in price, or if it extends over a substantial period of time, the result may be different. Williams in "Oil and Gas Law" argues in support of the dicta in the Denker case that "production" should be construed with regard to "normal conditions". .9

The lessee has a fairly strong argument for holding the lease by nonpaying production during a period when temporary depression prevents paying production. Clearly the lessee is not holding the land merely for speculative purposes, since under normal conditions the lease is presently producing in paying quantities. If the lessor is receiving a financial benefit from production, and if present production under normal conditions would be in paying quantities, and if the lessee in good faith decides that he can better himself financially in the long run from production at the present rate, the better rule would seem to be to allow the lessee to continue to hold the lease, despite a current loss due to depressed market conditions. Such a rule would not only avoid conflict with the policy against holding leases for purely speculative purposes, but in periods of sharp depression in the oil and gas industry, it would provide essential relief to all operators.

The difficulty is that it is not possible to determine a "normal" price of oil and gas or to determine when former price levels will be restored, if ever. It is suggested that the proper approach is that dictated by Clifton v. Koontz. A fall in price is a factor to be considered in determining whether a reasonably prudent operator would continue to hold the lease. It will likely cause the termination of the lease if the fall is not temporary and the loss is substantial. In these circumstances prospects for the establishment of profitable production are not good and the holding of the lease by the lessee is mere specualtion.

The change in oil and gas prices in 1986 arose from a fundamental change in supply and demand. The current level of prices is "normal" in the sense that it represents the market response to that changed supply and demand. The changes in supply and demand were not temporary, nor was the change in price. To allow a lessee to hold land waiting for the fundamentals of supply and demand for oil and gas to change is to encourage speculation to the detriment of the lessor. This is what the courts' interpretation of the habendum of the oil and gas lease has strived to avoid.

68. 648 P.2d 14, (Okla. 1982).

69. H.R. Williams, Supra, note 4l, at s. 604.6(c). 


\section{THE RIGHT TO SHUT-IN ${ }^{70}$}

An oil and gas well ordinarily terminates upon the expiration of the primary term if oil or gas is not produced unless there is a saving provision. The shut-in clause was introduced to address the problem where a well is capable of production but could not be produced for lack of a market. It has been judicially explained: ${ }^{71}$

Shut-in or in lieu royalties were devised to benefit both the lessor and lessee from the standpoint of insuring exploration for and the production of minerals in paying quantities so that both parties may reap the expected benefits. A clause embracing such a provision is for the purpose of protecting the lessor where there are wells capable of producing in paying quantities but where no market can be found for such production. Under this type of clause the lessor or royalties owner is paid a stipulated sum while the production is shut-in. At the same time the lease is maintained instead of being cancelled for lack of production.

It was included in the form of oil and gas lease, derived from the United States Producers 88 form, adopted in Canada after Leduc. ${ }^{72} \mathrm{~A}$ typical clause provided: ${ }^{73}$

Provided no royalties are otherwise paid hereunder, the lessee shall pay to the lessor each year as royalty the sum of fifty dollars $(\$ 50.00)$ for all wells on the said lands where gas only or primarily is found and the same is not used or sold, and while the said royalty is so paid each such well shall be deemed to be a producing well hereunder. [Shell]

The clause was confined to gas wells. The problem of marketing was considered to be confined to gas due to pipeline, storage and marketing practices associated with gas production. The clause does not, however, refer to these reasons for shutting-in the well.

Since that time changes have been introduced which have sought to expand the right of the lessee to shut-in a well and yet maintain the lease in effect. This has been accomplished by expanding the right to include all wells, whether oil or gas, as in:

\section{Suspended Wells}

If, at the expiration of the primary term or at any time or times thereafter, there is any well on the said lands, the pooled lands, or the unitized lands, capable of producing the leased substances or any of them, and all such wells are shut-in or suspended, this Lease shall, nevertheless, continue in force as though operations were being conducted on the said lands, for so long as all the said wells are shut-in or suspended and so long thereafter as operations are conducted upon the said lands, the pooled lands or the unitized lands, with no cessation, in the case of each cessation of operations, of more than 90 consecutive days. [C.A.P.L. 88]

Other clauses that were in use shortly after Leduc did particularize the reasons for which a well could be shut-in:

Where all wells on the said lands producing, or capable of producing, gas only are shut-in, suspended, capped or otherwise not being produced as the result of the lack of or an intermittent market, lessee may pay as royalty the sum of $\$ 100.00$ per well per year, and if such payment is made it will be considered that gas is being produced on the said lands.

70. See generally: J.B. Newman and T.M. Hughes: "Selected Topics with Respect to the Freehold Oil and Gas Lease: Top Lease, Estoppel and Shut-in Royalties” (1985), 24 Alta L. Rev. 81 . J.S. Lowe: "Shut-in Royalty Payments". Chapter 18, Eastern Mineral Law Foundation, 5th Am.L.Inst. 1984. N.J. Forbis "The Shut-In Royalty Clause: Balancing the Interests of Lessors and Lessees" (1989) 67 Tex.L.Rev. 1129.

71. Davis v. Lasıer 242 La. 735, 138 S.2d 558, 96 A.L.R. (2d) 332 (1962).

72. See D.E. Lewis, Supra, note 25.

73. Ibid., at fn. 16. See Shell Oil v. Gunderson, supra, note 31, where a lease was entered into in 1950 with such a clause. 
A modern variant of the clause deleted the limitation to gas wells and added as a reason for shutting-in a well "any cause whatsoever beyond the lessee's reasonable control", as follows:

If all wells on the said lands or the pooled lands are shut-in, suspended or otherwise not produced during any year ending on an anniversary date as the result of a lack of or an intermittent market, or any cause whatsoever beyond the Lessee's reasonable control, the Lessee shall pay to the Lessor at the expiration of each said year a sum equal to the delay rental hereinbefore set forth, and each such well shall be deemed to be a producing well hereunder. [Esso Resources 589 7A (Alta.)]

A variant on the wording is "for any cause whatsoever" [Conoco]. Other leases have added as a reason to shut-in a well "the lack of an economical or profitable market."

To what extent do these clauses overcome the problem posed for the lessee by low oil and gas prices? Can the lessee shut-in the well and yet maintain the lease in effect when receipts are insufficient to establish production in paying quantities? Ballem has described the position of the lessee under a clause which does not expressly state conditions under which a well may be shut-in, such as in the CAPL 88 lease, as "invincible". ${ }^{74} \mathrm{He}$ has suggested that "all the lessee has to establish is that there is a well and that the well is shut-in".

The interests of a lessor and lessee are unlikely to coincide. A lessor may well prefer production royalties to nominal shut-in royalties, and could obtain substantial benefits upon the negotiation of a new lease. Moreover, a lessor may fear drainage from neighbouring wells whilst the well on the leased lands is shut-in. The lessee, on the other hand, would much prefer to be able to shut-in a well and maintain a lease at minimal cost until prices recover.

Only one Canadian decision has considered the reasons upon which a lessee may exercise a right to shut-in a well. In Blair Estate v. Altana Exploration Co. ${ }^{75}$ the lessee sought to maintain a caveat, filed with respect to a lease, by demonstrating that a gas well had been shut-in on account of a "lack of or an intermittent market, or any cause whatsoever beyond the lessee's reasonable control". The Alberta Court of Appeal in a brief judgment determined that the onus lay upon the lessee to establish the existence of those circumstances and the lessee had failed to meet that onus. Irving J.A. explained for the Court:

\footnotetext{
"The evidence adduced by the respondent supported the inference that insofar as its major customer, Trans-Canada Pipelines, was concerned the market was intermittent. However, there was also evidence of a different potential market described as being "discount commercial markets". In our view the evidence did not demonstrate a lack of such an alternate market. Accordingly, the respondent did not prove that there was a lack of market for the natural gas product in order to trigger the extension of the primary term of the lease.

We therefore conclude that the learned chambers judge erred in drawing the inference he did in the absence of any supporting evidence as it related to the alternate discount commercial market. " "7n
}

The Court considered that the lessee must show an inability to market at any price, discounted or not.

In the United States much greater attention has been directed to the circumstances in which a well may be shut-in. It is "generally said that payment of shut-in royalty will not suffice to hold a lease unless the shut-in well is capable of paying produc-

74. J.B. Ballem, supra, note 15 at 149.

75. (1987), 53 Alta L.R. (2d) 419, [1987] Alta. D. 2193-01. Reproduced in Lewis \& Thompson, supra, note 20, Dig. 370.

76. Ibid. 
tion." "7 Such has been explained as "in keeping with the fundamental idea that the perpetuation of a lease beyond the primary term should result only where there is a valid reason behind the continuation, which might conceivably result in appreciable financial gain to the lessor." 78

In Taylor v. Kimbell ${ }^{9}$ the Supreme Court of Louisana considered a clause where the right to shut-in was provided "where gas from a well, producing gas only, is not sold or used because of no market or demand." The Court declared:80

Under the plain terms of the lease contract, the primary term having expired, all rights granted the lessee under the lease have terminated unless the record shows that the gas well drilled on the premises can be classed as a producer in paying quantities and was shut in because of no market or demand for the gas.

The Court held that the lessee had failed to show that the well was capable of producing in paying quantities.

It is suggested that in view of the derivation from the United States of the form of the Canadian freehold oil and gas lease and the interpretation suggested to be appropriate with respect to the habendum in the Canadian lease, that a construction of the shut-in clause should be adopted in Canada similar to that of the United States. It would accord a reasonable purposive construction to the language of the clause and the lease. It would necessarily, of course, limit the "invincibility" of the lessee and give effect to a lease designed for the mutual benefit of both parties, and not merely the lessee.

One commentator responded to the United States jurisprudence by suggesting that the shut-in clause should be amended to refer specifically to any well, whether or not the well is capable of production in paying quantities.$^{81}$ None of the clauses presently used in Canada so provide. Rather, the amendments introduced in Canada have been directed to the reasons for shutting-in a well and have included oil wells. The actual wording of the lease, of course, governs.

Following Blair Estate, the only expressions which might address an incapacity to produce in paying quantities due to low oil and gas prices are: "for any cause whatsoever", "for any cause whatsoever beyond the lessee's reasonable control", and "for lack of an economical or profitable market". In Canada-Cities Service Petroleum v. Kininmonth" result of any cause whatsoever beyond the lessee's control"'. The Court held that road bans were not such a cause. Smith C.J.A. observed that the "closing of the roads could and should have been anticipated by the [lessee]." ${ }^{83}$ Porter J.A. observed with respect to the road ban and an order of the Conservation Board requiring the shutting-in of the well that "the problem the lessee pleads as being beyond its control was completely foreseeable." ${ }_{84}$ The dicta suggests that a matter will only be consid-

77. H.R. Williams, supra, note 41 , s. 632.3 and references.

78. Scurlock, "Practical and Legal Problems in Delay Rental and Shut-in Royalty Payments" (1953) 4 Sw.Legal Found. Inst. on Oil \& Gas L. \& Tax. 17 at 45.

79. 54 So.2d (1951). And see Ray v. Premier Petroleum 662 P.2d 255 (1983).

80. lbid. at 2.

81. W.D. Masterson, "The Shut-In Royalty Clause in an Oil and Gas Lease" (1958) 4 Rocky Mt. MinL. Inst. 315 and 330.

82. (1963), 42 D.L.R. (2d) 56 (Alta C.A.).

83. Ibid.

84. Ibid. at 75 . 
ered to be beyond the lessee's control if it was not foreseeable at the time of the drilling of the well. A downturn in prices after the well has been drilled may be argued to be a cause "beyond the lessee's reasonable control" which will enable the lessee to shut-in a well. But if volatility of oil and gas prices is recognized as part of the nature of the oil and gas business, then neither declines nor rises in prices should properly be considered unforseeable. If the condition of the right to shut-in is "for any cause whatsoever", the lessee may be entitled to shut-in the well whether or not there was an unforeseen fall in prices. ${ }^{85}$

The expression "lack of an economical or profitable market" would seem to come closest to directly addressing the requirement, otherwise considered to exist, of a well capable of "producing in paying quantities". The terms "economical" and "profitable" are suggested in this context to be essentially synonymous and to contemplate a right to shut-in the well where production cannot be obtained profitably, that is "in paying quantities".

\section{CONCLUSION}

Low oil and gas prices present major problems in the maintenance of freehold oil and gas leases. Both Canadian and United States authorities indicate that leases will terminate if production is not "in paying quantities". The standard of the reasonably prudent operator suggests that a lessee cannot hold a well for anything more than a temporary period whilst operating at a loss. The lessee cannot hold the land by production which results in losses to itself and reduced royalties to the lessor, when fundamental changes in supply and demand have brought about a fall in prices.

Further, most shut-in clauses do not assist the lessee. The clauses generally assume the existence of a well capable of production "in paying quantities". However, the "actual wording" must govern and some clauses provide for "economical" or "unprofitable" markets and thereby specifically address the lessee's dilemma.

85. In Durish v. White Resource Mgt. (1987), 55 Alta L.R. (2d) 47 (Q.B.) affirmed, (1988), 63 Alta L.R. (2d) 265 (C.A.) the Court did not consider that a lessee could rely on a shut-in clause which referred to "any cause whatsoever which is in accordance with oil field practice". The Court held that a contract dispute as to transmission and processing fees between a lessee and an operator did not come within the ambit of "good oilfield practice".

However, Bracco J. did refer to the possibility that there might be such a cause if the "revised fees make continued production impossible or unprofitable": Ibid. at 53-54 (Q.B.). But there was no such evidence before the Court. 


\section{APPENDIX I}

Post-Leduc cases where United States jurisprudence was considered directly or indirectly (via its adoption in a previous Canadian case) in the interpretation of freehold oil and gas leases.

1951

Wetter v. New Pecalta Oils, [1951] 2 W.W.R. 290 (Alta C.A.) - applied U.S.

Oil Ciny v. American Leduc (1951), 2 W.W.R. 371 (C.A.) - applied U.S. affirmed [1952] 3 D.L.R. 577

(S.C.C.).

1952

East Crest Oil v. Strohschein (1952), 4 W.W.R. 553. [1952] 2 D.L.R. 432 (Alta C.A.) - applied U.S.

Setter v. Mander (1952), 6 W.W.R. 577 - applied East Crest.

Rostad v. Andreassen (1952), 7 W.W.R. 709 - applied East Crest and U.S. affirmed (1953), 8 W.W.R. 717 (Alta C.A.).

1953

Reynolds v. Ackerman, [1953] 31 W.W.R. 289 (Alta S. Ct.) - applied East Crest.

1955

Chipp v. Hunt, [1955] 16 W.W.R. 209 (Alta S. Ct.) - applied East Crest.

1956

Canadian Fina Oil v. Paschke (1956), 19 W.W.R. 184, (1957), 21 W.W.R. 260 (Alta C.A.) - applied East Crest.

1957

Albrecht v. Imperial Oil (1957), 21 W.W.R. 560 (Alta S. Ct.) - applied U.S.

Langlois v. Canadian Superior Oil (1957), 23 W.W.R. 401 (Man. C.A.) - applied East Crest and U.S.

1960

Krysa v. Opalinski (1960), 32 W.W.R. 346 (Alta S. Ct.) - applied East Crest.

1961

Shell Oil Co. v. Gibbard (1961), 34 W.W.R. 117 (Alta C.A.) - considered and applied U.S. - but not in S.C.C.

1964

Canada Cities Service v. Kininmonth (1963), 42 D.L.R. 56 (Alta C.A.) - considered and applied U.S. [1964] S.C.R. - considered U.S.

Prudential Trust v. National Trust (1964), 50 W.W.R. 29 (Alta S. Ct.) - considered and applied U.S.

Canadian Superior Oil v. Kanstrup (1964), 47 W.W.R. 129 (Alta C.A.) - applied East Crest, [1965] S.C.R. 92 affirmed.

1969

Canadian Superior Oil v. Murdoch (1969), 68 W.W.R. 390 (Alta C.A.), (1969), 70 W.W.R. 768 (S.C.C.) applied Kininmonth and Kanstrup.

Canadian Superior Oil v. Hambly (1969), 67 W.W.R. 525 (Alta C.A.). (1970), 74 W.W.R. 356 (S.C.C.) applied in Kanstrup.

Sohio Petroleum v. Weyburn Security (1969), 69 W.W.R. 680 (Alta C.A.), (1970), 74 W.W.R. 626 (S.C.C.) - applied Kininmonth.

1981

Republic Resources v. Ballem (1981), 17 Alta L.R. (2d) 235 (Q.B.) - applied Kininmonth.

1982

Canadian Superior Oil v. Crozet Exploration (1982), 33 D.L.R. (3d) 53 (Alta Q.B.) - applied U.S.

1985

Kissinger Petroleums v. Keith McLean Oil et al. (1985), 33 Alta L.R. (2d) I (C.A.) - applied U.S.

1986

Esso Resources v. Pacific Cassiar, [1986] 4 W.W.R. 385 (Alta C.A.) - applied U.S. 
1987

Durish v. White Resource Management (1987), 55 Alta L.R. (2d) 47 (Q.B.), (1988) 63 Alta L.R. (2d) 265 (C.A.). - applied East Crest and Kanstrup.

\section{APPENDIX II}

Post-Leduc cases where United States jurisprudence was not considered directly or indirectly.

1956

Canadian Fina Oil v. Paschke (1956), 19 W.W.R. 184, (1957), 21 W.W.R. 260 (C.A.) - not considered with respect to time of payment.

1960

Shell Oil v. Gunderson (1959), 28 W.W.R. 506. [1960] S. C.R. 424.

1961

Shell Oil Co. v. Gibbard, [1961] S.C.R. 725.

1964

Canadian Superior Oil v. Kanstrup (1964), 47 W.W.R. 129 (Alta C.A.), [1965] S.C.R. 92 - applied Gunderson.

1970

Texas Gulfv. Ballem (1970), 72 W.W.R. 273 (Alta C.A.) - rejected Paschke.

Paramount Petroleum v. Imperial Oil (1970), 73 W.W.R. 417 (Sask. Q.B.) - applied Ballem, rejected Paschke.

1972

Cull v. Canadian Superior Oil, [1972] S.C.R. 89. 